\title{
Effects of Caragana microphylla plantations on organic carbon sequestration in total and labile soil organic carbon fractions in the Horqin Sandy Land, northern China
}

\author{
SHANG Wen ${ }^{1,2}$, LI Yuqiang ${ }^{2 *}$, ZHAO Xueyong ${ }^{2}$, ZHANG Tonghui ${ }^{2}$, MA Quanlin ${ }^{1}$, TANG \\ Jinnian $^{1}$, FENG Jing ${ }^{2}$, SU Na ${ }^{2}$ \\ ${ }^{1}$ State Key Laboratory Breeding Base of Desertification and Aeolian Sand Disaster Combating, Gansu Desert Control Research \\ Institute, Lanzhou 730070, China; \\ ${ }^{2}$ Naiman Desertification Research Station, Northwest Institute of Eco-Environment and Resources, Chinese Academy of \\ Sciences, Lanzhou 730000, China
}

\begin{abstract}
Afforestation is conducive to soil carbon (C) sequestration in semi-arid regions. However, little is known about the effects of afforestation on sequestrations of total and labile soil organic carbon (SOC) fractions in semi-arid sandy lands. In the present study, we examined the effects of Caragana microphylla Lam. plantations with different ages (12- and 25-year-old) on sequestrations of total SOC as well as labile SOC fractions such as light fraction organic carbon (LFOC) and microbial biomass carbon (MBC). The analyzed samples were taken from soil depths of $0-5$ and $5-15 \mathrm{~cm}$ under two shrub-related scenarios: under shrubs and between shrubs with moving sand dunes as control sites in the Horqin Sandy Land of northern China. The results showed that the concentrations and storages of total SOC at soil depths of $0-5$ and $5-15 \mathrm{~cm}$ were higher in 12- and 25-year-old C. microphylla plantations than in moving sand dunes (i.e., control sites), with the highest value observed under shrubs in 25-year-old C. microphylla plantations. Furthermore, the concentrations and storages of LFOC and MBC showed similar patterns with those of total SOC at the same soil depth. The 12-year-old C. microphylla plantations had higher percentages of LFOC concentration to SOC concentration and MBC concentration to SOC concentration than the 25-year-old C. microphylla plantations and moving sand dunes at both soil depths. A significant positive correlation existed among SOC, LFOC, and MBC, implying that restoring the total and labile SOC fractions is possibleby afforestation with C. microphylla shrubs in the Horqin Sandy Land. At soil depth of 0-15 cm, the accumulation rate of total SOC under shrubs was higher in young C. microphylla plantations $\left(18.53 \mathrm{~g} \mathrm{C} /\left(\mathrm{m}^{2} \cdot \mathrm{a}\right) ; 0-12\right.$ years) than in old C. microphylla plantations $\left(16.24 \mathrm{~g} \mathrm{C} /\left(\mathrm{m}^{2} \cdot a\right) ; 12-25\right.$ years $)$, and the accumalation rates of LFOC and MBC under shrubs and between shrubs were also higher in young $C$. microphylla plantations than in old C. microphylla plantations. It can be concluded that the establishment of C. microphylla in the Horqin Sandy Land may be a good mitigation strategy for SOC sequestration in the surface soils.
\end{abstract}

Keywords: Caragana microphylla plantation; soil organic carbon; light fraction organic carbon; microbial biomass carbon; carbon accumulation rate; Horqin Sandy Land

Citation: SHANG Wen, LI Yuqiang, ZHAO Xueyong, ZHANG Tonghui, MA Quanlin, TANG Jinnian, FENG Jing, SU Na. 2017. Effects of Caragana microphylla plantations on organic carbon sequestration in total and labile soil organic carbon fractions in the Horqin Sandy Land, Northern China. Journal of Arid Land, 9(5): 688-700. doi: 10.1007/s40333-017-0063-x

${ }^{*}$ Corresponding author: LI Yuqiang (E-mail: liyq@1zb.ac.cn)

Received 2017-01-13; revised 2017-05-24; accepted 2017-07-12

(C) Xinjiang Institute of Ecology and Geography, Chinese Academy of Sciences, Science Press and Springer-Verlag GmbH Germany 2017 


\section{Introduction}

Land degradation and desertification are widespread phenomena in arid and semi-arid regions, leading to a decrease in plant diversity and a reduction in biological productivity and complexity (UNCCD, 1994; Higginbottom and Symeonakis, 2014). Furthermore, they can also decrease global soil carbon (C) pools and soil C sinking capacity (Lal, 2001, 2014). Afforestation, which refers to the conversion of treeless lands into forestlands, can effectively control soil erosion and land degradation in ecologically fragile areas (Berthrong et al., 2012; Deng and Shangguan, 2016). Carbon dioxide $\left(\mathrm{CO}_{2}\right)$ fixed in plant biomass through afforestation inevitably impacts the quality, quantity and spatial and temporal dynamics of soil organic carbon (SOC) pools (Paul et al., 2002; Berthrong et al., 2012). Understanding the dynamics of SOC pools following afforestation is critical for the development of terrestrial forest conservation and management strategies. However, no consensus has yet been reached regarding the effects of afforestation on SOC sequestration. Recent studies have suggested that afforestation might increase (Post and Kwon, 2000; Li et al., 2012; Xie et al., 2013; Wang et al., 2016; Han et al., 2017), initially decrease and later increase (Deng et al., 2014; Wang et al., 2014), or exert negligible effects (Rytter, 2016) on SOC sequestration. Multiple factors, such as climate conditions, land-use types, soil types and plantation species, etc. may lead to inconsistent results (Paul et al., 2002; Laganière et al., 2010; Deng and Shangguan, 2016).

Labile SOC fractions, rather than total SOC, exhibit rapid turnover rates (Wissing et al., 2011). Labile SOC fraction is a representative indicator of plant-available nutrients because its dynamics have crucial implications in soil nutrient supply (Berthrong et al,, 2012). In addition, labile SOC fractions sensitively respond to land-use changes. Laik et al. (2009) reported that afforestation can increase labile SOC fractions with different magnitudes, and labile SOC fractions respond more sensitively to afforestation than total SOC does. Light fraction organic carbon (LFOC) and microbial biomass carbon (MBC) are important compositions of labile SOC fractions. There are many studies that investigated the spatial and temporal dynamics of total SOC and labile SOC fractions caused by afforestation in tropical, subtropical and temperate regions (Laik et al., 2009; Arai and Tokuchi, 2010; Li et al., 2012; Bárcena et al., 2014; Liu et al., 2015), and the results demonstrated that afforestation exerts a greater impact on labile SOC fractions (such as LFOC and $\mathrm{MBC}$ ) than on total SOC. However, quite few studies have explored the effects of afforestation on sequestration patterns of total and labile SOC fractions (e.g., Arai and Tokuchi, 2010; Bárcena et al., 2014). In addition, most of these related studies mainly focused on former agricultural lands (Laik et al., 2009; Bárcena et al., 2014) or former pastures (Hu et al., 2008; Arai and Tokuchi, 2010), while scarcely paid attention to former degraded sandy lands (or moving sand dunes), especially those in semi-arid sandy regions.

The Horqin Sandy Land, situated in the semi-arid agro-pastoral ecotone of northern China, is one of the most severely degraded regions in China (Su and Zhao, 2003; Zhao et al., 2007). Long-term overgrazing and increased human disturbances in the Horqin Sandy Land have changed the landscape from tree-scattered grasslands into moving sand dunes ( $\mathrm{Li}$ et al., 2012; Wang et al., 2013). Thus, a series of environmental protection measurements, such as fencing of grasslands and planting of plants (trees, shrubs and grasses), were implemented since 2000 in the sandy lands to mitigate land degradation and desertification (Su and Zhao, 2003; Cao et al., 2008). Caragana microphylla Lam., a pioneer leguminous shrub with high drought resistance and high adaptation to poor soil nutrition, is generally used for the rehabilitation of severely degraded lands in the Horqin Sandy Land (Zhang et al., 2006; Yue et al., 2008; Wang et al., 2013). A large number of $C$. microphylla shrubs have been planted as sand binders on degraded lands in the Horqin Sandy Land (Zhao et al., 2007). Many studies have investigated the effects of $C$. microphylla plantations on soil physical-chemical properties ( $\mathrm{Su}$ and Zhao, 2003; Zhao et al., 2007), shrub transpiration rate (Yue et al., 2008), nutrient resorption ( $\mathrm{Li}$ et al., 2012), soil microbial community and enzyme activity (Cao et al., 2008; Wang et al., 2013), and genetic diversity (Huang et al., 2016). However, knowledge about whether C. microphylla plantation is the most ecologically appropriate way for ecological restoration in the Horqin Sandy land, 
especially in terms of SOC sequestration, is unclear (Lai et al., 2017). In addition, the sequestration patterns of SOC may vary greatly among different SOC fractions and plantation ages of C. microphylla. The scientific identification of shrub plantations in degraded lands that combines the sequestrations of total and labile SOC fractions is essential for $\mathrm{C}$ estimation and management at regional and global scales.

The main objectives of this study were: (1) to evaluate the amounts of organic carbon in terms of total SOC and labile SOC fractions (including LFOC and MBC) in different-aged C. microphylla plantations in the Horqin Sandy Land; and (2) to obtain a further understanding on which SOC fraction responds to $C$. microphylla plantations more sensitively. It is our hope that this study could provide scientific reference on the effects of C. microphylla plantations on SOC sequestration in the Horqin Sandy Land and also for other similar regions.

\section{Materials and methods}

\subsection{Study area}

The study was conducted in Yaoledianzi Village $\left(42^{\circ} 55^{\prime} \mathrm{N}, 120^{\circ} 41^{\prime} \mathrm{E} ; 350 \mathrm{~m}\right.$ a.s. 1$)$ located in the southwestern part of the Horqin Sandy Land, Inner Mongolia Autonomous Region, northern China. The study area has a temperate continental semi-arid monsoon climate with annual mean air temperature of $6.4^{\circ} \mathrm{C}$, mean annual precipitation of $362 \mathrm{~mm}$, and mean annual potential evaporation of $1935 \mathrm{~mm}$. The annual mean wind speed is $3.4 \mathrm{~m} / \mathrm{s}$. It should be noted that wind speed in spring is rather high, reaching up to $4.3 \mathrm{~m} / \mathrm{s}$ (Zhao et al., 2007; Li et al., 2012). Landscapes in this region are dominated by gently undulating semi-stable and moving sand dunes (Zhao et al., 2007). The soil is characterized by loose structure and coarse texture with high sand proportion $(85 \%-95 \%)$ and low organic matter content $(0.15-0.5 \mathrm{~g} / \mathrm{kg}$ organic C) (Su and Zhao, 2003; Yue et al., 2008), thus it is prone to wind erosion. The major soil type is classified into the Entisol order, Semiaripsamment group according to the United States Soil Classification System (Duan et al., 2007).

\subsection{Experimental design and soil sampling}

In this study, 12- and 25-year-old C. microphylla plantation fields afforested in moving sand dunes surrounding the Yaoledianzi Village were selected as study sites. All of these plantation fields have been subjected to light grazing in recent years (Li et al., 2012). These shrubs were planted on moving sand dunes and arranged in belts with row spacing of 1.5-2.0 m and plant spacing of $0.5 \mathrm{~m}$. Field investigations were conducted in June 2011. For each age class (12- and 25-year-old C. microphylla), three replicated stands were selected. In addition, three moving sand dunes with no vegetation were selected as three control sites ( 0 -year age of $C$. microphylla). It should be noted that each control site (moving sand dune) was adjacent to a plantation site. Totally, 9 sampling sites were established. For each sampling site, a $30 \mathrm{~m} \times 30 \mathrm{~m}$ plot was established for soil sampling. Characteristics of the sampling sites are shown in Table 1.

Table 1 Characteristics of the sampling sites

\begin{tabular}{|c|c|c|c|c|}
\hline \multicolumn{2}{|l|}{ Site } & $\begin{array}{l}\text { Mean plant height } \\
(\mathrm{cm})\end{array}$ & $\begin{array}{l}\text { Crown diameter } \\
(\mathrm{cm} \times \mathrm{cm})\end{array}$ & $\begin{array}{c}\text { Number of shoots } \\
(N)\end{array}$ \\
\hline \multicolumn{2}{|c|}{ Control site (moving sand dune; 0 -year age of C. microphylla) } & - & - & - \\
\hline \multirow{2}{*}{ C. microphylla plantation site } & 12-year-old & 89 & $80 \times 76$ & 45.18 \\
\hline & 25-year-old & 110 & $88 \times 90$ & 38.42 \\
\hline
\end{tabular}

Note: "-" means no data.

For each moving sand dune (0-year age of C. microphylla), soil samples were taken from 9 random locations at two soil depths $(0-5$ and 5-15 cm) in each plot. Moreover, soil samples from 0-5 cm depth were taken using a shovel, and soil samples from 5-15 cm depth were taken using a soil auger with a diameter of $2.5 \mathrm{~cm}$. For each plantation site (12- and 25-year-old C. microphylla plantations $)$, three parallel belts $(1.5-2.0 \mathrm{~m}$ width $\times 30 \mathrm{~m}$ length each) were established in each plot 
and four sampling locations (two under shrubs and two between shrubs) were chosen in each belt. At each location (under shrubs and between shrubs), a composite soil sample for each soil depth $(0-5$ and 5-15 cm) was collected from 8-12 random core points using a soil auger with a diameter of $2.5 \mathrm{~cm}$. It should be pointed out that soil samples under shrubs were collected from the beneath of shrubs.

To measure soil bulk density in moving sand dunes (control sites) and 12- and 25-yar-old C. microphylla plantation sites, we additionally sampled 6 soil cores (three under shrubs and three between shrubs for each C. microphylla plantation site) from each soil depth $(0-5$ and $5-15 \mathrm{~cm})$ using a cylindrical steel soil auger with a volume of $100 \mathrm{~cm}^{3}$ (diameter of $5 \mathrm{~cm}$ and height of 5 $\mathrm{cm})$ at each sampling site.

\subsection{Laboratory analyses}

The collected soil samples were sieved through a 2-mm mesh to remove visible plant roots, rocks and other debris. Then, each of soil samples was divided into two parts. One part was stored in a fridge at $4^{\circ} \mathrm{C}$ for MBC (microbial biomass carbon) determination. The other part was air-dried at room temperature to determine soil $\mathrm{pH}$, particle size distribution, SOC concentration, total nitrogen (TN) concentration, and light fraction. Specifically, MBC concentration $(\mathrm{g} / \mathrm{kg})$ was determined using the chloroform fumigation extraction method (Vance et al., 1987). Soil pH was measured in a soil-water suspension (soil:water ratio=1:2.5) (Sartorius PB-21, Germany). Soil particle size was determined by the wet sieving method with sodium hexametaphosphate as the dispersing agent (ISO, 1998). The particle size as classified into three fractions: coarse sand $(2.00-0.10 \mathrm{~mm})$, fine sand $(0.10-0.05 \mathrm{~mm})$, and silt + clay $(<0.05 \mathrm{~mm})$. SOC concentration $(\mathrm{g} / \mathrm{kg})$ was estimated according to the Walkley-Black dichromate oxidation method, and TN concentration $(\mathrm{g} / \mathrm{kg}$ ) was measured using the Kjeldahl method (Li et al., 2012). A modified method of Janzen et al. (1992) was used to isolate the light fraction (LF) with a density of 1.7 $\mathrm{g} / \mathrm{cm}^{3}$. The LF dry matter content was expressed as a percentage of the total soil mass $(\mathrm{g})$. The light fraction organic carbon (LFOC) concentration $(\mathrm{g} / \mathrm{kg}$ soil) was measured according to the Walkley-Black method.

\subsection{Statistical analyses}

In this study, total SOC storage $\left(\mathrm{g} / \mathrm{m}^{2}\right)$, LFOC storage $\left(\mathrm{g} / \mathrm{m}^{2}\right)$ and MBC storage $\left(\mathrm{g} / \mathrm{m}^{2}\right)$ for each soil layer were calculated according to the following equations ( $\mathrm{Li}$ et al., 2012; Tang and $\mathrm{Li}$, 2013):

$$
\begin{aligned}
& \text { Total SOC storage }=S O C \text { concentration } \times B D \times H, \\
& \text { LFOC storage }=L F O C \text { concentration } \times \text { light fraction dry matter content } \times B D \times H, \\
& M B C \text { storage }=M B C \text { concentration } \times B D \times H,
\end{aligned}
$$

where $B D$ is the soil bulk density $\left(\mathrm{g} / \mathrm{cm}^{3}\right)$ and $H$ is the soil depth $(\mathrm{cm})$.

All the data were analyzed by one-way ANOVA and least significant difference (LSD) tests were also used to test for differences among sampling sites. Differences at $P<0.05$ level were considered statistically significant. Pearson's correlation analysis was performed to evaluate the relationship between SOC fractions. The statistical analysis was performed using SPSS 16.0 software (SPSS Inc., Chicago, IL, USA).

\section{Results}

\subsection{Soil physical-chemical properties}

Soil physical-chemical properties at different soil depths in moving sand dunes (i.e., control sites) and in 12- and 25-year-old C. microphylla plantations are shown in Table 2. For soil particle size distribution, the coarse sand content in moving sand dunes was significantly higher than those in 12- and 25-year-old C. microphylla plantations at both $0-5$ and $5-15 \mathrm{~cm}$ soil depths $(P<0.05)$. For both age groups of $C$. microphylla plantations (12- and 25-year-old), the coarse sand contents under shrubs were all lower than those between shrubs at $0-5 \mathrm{~cm}$ soil depth. No significant difference in soil bulk density was observed between 12-year-old C. microphylla plantations and 
25-year-old C. microphylla plantations $(P>0.05)$, and soil bulk density was higher in moving sand dunes than in C. microphylla plantations (either 12- or 25-year-old).

At $0-5 \mathrm{~cm}$ soil depth, SOC concentrations under shrubs in 12- and 25-year-old C. microphylla plantations were 9.15 and 20.30 times higher than that in moving sand dunes, respectively; while SOC concentrations between shrubs in 12- and 25-year-old C. microphylla plantations were 4.97 and 14.36 times higher than that in moving sand dunes, respectively. The results indicate that after afforestation in moving sand dunes, SOC concentration increases with increasing plantation age. Furthermore, the C:N ratio was lower in moving sand dunes than that in 12- and 25-year-old C. microphylla plantations, indicating that afforestation increases soil $\mathrm{C}: \mathrm{N}$ ratio.

Table 2 Soil physical-chemical properties at different soil depths in moving sand dunes (controls; 0 -year age of C. microphylla) and in 12- and 25-year-old C. microphylla plantations

\begin{tabular}{|c|c|c|c|c|c|c|}
\hline \multirow{3}{*}{ Parameter } & \multirow{3}{*}{$\begin{array}{l}\text { Soil depth } \\
\quad(\mathrm{cm})\end{array}$} & \multirow{3}{*}{$\begin{array}{l}\text { Moving sand } \\
\text { dunes }\end{array}$} & \multicolumn{4}{|c|}{ C. microphylla plantations } \\
\hline & & & \multicolumn{2}{|c|}{ 12-year-old } & \multicolumn{2}{|c|}{ 25-year-old } \\
\hline & & & $\begin{array}{l}\text { Under } \\
\text { shrubs }\end{array}$ & $\begin{array}{c}\text { Between } \\
\text { shrubs }\end{array}$ & $\begin{array}{l}\text { Under } \\
\text { shrubs }\end{array}$ & $\begin{array}{c}\text { Between } \\
\text { shrubs }\end{array}$ \\
\hline \multirow{3}{*}{$\begin{array}{c}\text { Coarse sand } \\
(2.00-0.10 \mathrm{~mm} ; \%)\end{array}$} & $0-5$ & $97.31 \pm 0.26^{\mathrm{a}}$ & $89.15 \pm 1.03^{b}$ & $92.48 \pm 0.62^{b}$ & $p$ & $75.08 \pm 1.95^{\mathrm{c}}$ \\
\hline & $5-15$ & $97.51 \pm 0.27^{\mathrm{a}}$ & $93.18 \pm 0.50^{\mathrm{b}}$ & $93.87 \pm 0.58^{\mathrm{ab}}$ & $83.56 \pm 1.51^{\mathrm{c}}$ & $85.15 \pm 1.10^{\mathrm{c}}$ \\
\hline & $0-15$ & $97.41 \pm 0.18^{\mathrm{a}}$ & $91.16 \pm 0.66^{\mathrm{b}}$ & $93.17 \pm 0.4$ & $79.13 \pm 1.33^{\mathrm{c}}$ & $80.12 \pm 1.39^{\mathrm{c}}$ \\
\hline \multirow{3}{*}{$\begin{array}{c}\text { Fine sand } \\
(0.10-0.05 \mathrm{~mm} ; \%)\end{array}$} & $0-5$ & $2.28 \pm 0.23^{\mathrm{c}}$ & $8.42 \pm 0.81^{\mathrm{b}}$ & 5064 & $18.02 \pm 1.24^{\mathrm{a}}$ & $17.54 \pm 1.37^{\mathrm{a}}$ \\
\hline & $5-15$ & $2.13 \pm 0.24^{\mathrm{c}}$ & $5.40 \pm 0.44^{\mathrm{b}}$ & & $12.28 \pm 1.19^{\mathrm{a}}$ & $11.34 \pm 0.77^{\mathrm{a}}$ \\
\hline & $0-15$ & $2.20 \pm 0.17^{\mathrm{c}}$ & $6.91 \pm 0.52^{\mathrm{b}}$ & $5.21 \pm 0.34^{b}$ & $15.15 \pm 0.98^{\mathrm{a}}$ & $14.44 \pm 0.93^{\mathrm{a}}$ \\
\hline \multirow{3}{*}{$\begin{array}{c}\text { Silt+clay } \\
(<0.05 \mathrm{~mm} ; \%)\end{array}$} & $0-5$ & $0.17 \pm 0.03^{\mathrm{c}}$ & $2.05 \pm 0.24^{\mathrm{b}}$ & $1.39 \pm 0.14^{\mathrm{b}}$ & $6.53 \pm 0.45^{\mathrm{a}}$ & $6.40 \pm 0.64^{\mathrm{a}}$ \\
\hline & $5-15$ & $0.13 \pm 0.02^{\mathrm{c}}$ & $1.12 \pm 0.09^{b}$ & $1.01 \pm 0.12^{b}$ & $3.78 \pm 0.34^{\mathrm{a}}$ & $2.97 \pm 0.32^{\mathrm{a}}$ \\
\hline & $0-15$ & $0.15 \pm 0.02^{\mathrm{c}}$ & $.58 \pm 0.15^{\mathrm{b}}$ & $1.20 \pm 0.10^{\mathrm{b}}$ & $5.15 \pm 0.36^{\mathrm{a}}$ & $4.68 \pm 0.46^{\mathrm{a}}$ \\
\hline \multirow{3}{*}{$\begin{array}{l}\text { Bulk density } \\
\qquad\left(\mathrm{g} / \mathrm{cm}^{3}\right)\end{array}$} & $0-5$ & $1.63 \pm 0.01^{\mathrm{a}}$ & $0.02^{\mathrm{c}}$ & $1.57 \pm 0.01^{\mathrm{b}}$ & $1.41 \pm 0.02^{\mathrm{c}}$ & $1.53 \pm 0.02^{\mathrm{b}}$ \\
\hline & $5-15$ & $1.61 \pm 0.01^{\mathrm{a}}$ & $1.59 \pm 0.01^{\mathrm{a}}$ & $1.61 \pm 0.01^{\mathrm{a}}$ & $1.58 \pm 0.02^{\mathrm{a}}$ & $1.60 \pm 0.01^{\mathrm{a}}$ \\
\hline & $0-15$ & $1.62 \pm 0.01 \mathrm{a}$ & $1.52 \pm 0.02^{\mathrm{bc}}$ & $1.59 \pm 0.01^{\mathrm{ab}}$ & $1.49 \pm 0.02^{\mathrm{c}}$ & $1.56 \pm 0.01^{\mathrm{b}}$ \\
\hline \multirow{3}{*}{$\mathrm{pH}$} & $0-5$ & $7.97 \pm 0.05^{\mathrm{b}}$ & $8.31 \pm 0.08^{\mathrm{a}}$ & $8.46 \pm 0.15^{\mathrm{a}}$ & $7.84 \pm 0.05^{\mathrm{b}}$ & $7.99 \pm 0.05^{\mathrm{b}}$ \\
\hline & $5-15$ & $7.75 \pm 0.05^{\mathrm{c}}$ & $8.09 \pm 0.16^{\mathrm{b}}$ & $8.40 \pm 0.05^{\mathrm{a}}$ & $8.04 \pm 0.11^{\mathrm{b}}$ & $7.96 \pm 0.04^{\mathrm{bc}}$ \\
\hline & $0-15$ & $786+004^{\mathrm{c}}$ & $8.20 \pm 0.09^{\mathrm{b}}$ & $8.43 \pm 0.08^{\mathrm{a}}$ & $7.94 \pm 0.06^{\mathrm{c}}$ & $7.97 \pm 0.03^{\mathrm{c}}$ \\
\hline \multirow{3}{*}{$\mathrm{SOC}(\mathrm{g} / \mathrm{kg})$} & $0-5$ & $0.33 \pm 0.03^{\mathrm{e}}$ & $3.02 \pm 0.20^{\mathrm{c}}$ & $1.64 \pm 0.11^{\mathrm{d}}$ & $6.70 \pm 0.37^{\mathrm{a}}$ & $4.74 \pm 0.52^{\mathrm{b}}$ \\
\hline & $5-15$ & $0.33 \pm 0.01^{\mathrm{c}}$ & $1.94 \pm 0.20^{\mathrm{ab}}$ & $1.44 \pm 0.05^{\mathrm{b}}$ & $3.02 \pm 0.28^{\mathrm{a}}$ & $2.47 \pm 0.22^{\mathrm{ab}}$ \\
\hline & & $0.33 \pm 0.01^{\mathrm{e}}$ & $2.48 \pm 0.21^{\mathrm{c}}$ & $1.54 \pm 0.06^{\mathrm{d}}$ & $4.86 \pm 0.60^{\mathrm{a}}$ & $3.61 \pm 0.44^{b}$ \\
\hline \multirow{3}{*}{$\mathrm{C} / \mathrm{N}$ ratio } & & $6.35 \pm 0.44^{\mathrm{c}}$ & $9.31 \pm 0.57^{\mathrm{ab}}$ & $8.85 \pm 0.41^{b}$ & $9.53 \pm 0.21^{\mathrm{ab}}$ & $10.03 \pm 0.48^{\mathrm{a}}$ \\
\hline & & $6.51 \pm 0.46^{\mathrm{b}}$ & $9.04 \pm 0.61^{\mathrm{a}}$ & $9.20 \pm 0.39^{\mathrm{a}}$ & $9.21 \pm 0.39^{\mathrm{a}}$ & $9.61 \pm 0.24^{\mathrm{a}}$ \\
\hline & $0-15$ & $6.43 \pm 0.31^{\mathrm{c}}$ & $9.18 \pm 0.315^{\mathrm{ab}}$ & $9.02 \pm 0.27^{\mathrm{b}}$ & $9.37 \pm 0.22^{\mathrm{ab}}$ & $9.82 \pm 0.27^{\mathrm{a}}$ \\
\hline
\end{tabular}

Note: SOC, soil organic carbon. Different lowercase letters within the same row represent significant differences among different sampling sites at $P<0.05$ level. Mean \pm SE; $n=9$.

\subsection{Total SOC storage}

Total SOC storage was highest in 25-year-old C. microphylla plantations and lowest in moving sand dunes at both $0-5$ and $5-15 \mathrm{~cm}$ soil depths (Fig. 1). At $0-5 \mathrm{~cm}$ soil depth, the total SOC storage values under shrubs in 12- and 25-year-old C. microphylla plantations were 8.15 and 17.65 times higher than that in moving sand dunes, respectively. At 5-15 cm soil depth, the total SOC storage values under shrubs in 12- and 25-year-old C. microphylla plantations were 5.81 and 9.00 times higher than that in moving sand dunes, respectively. These results indicate that afforestation in moving sand dunes could elevate the total SOC storage.

\subsection{LF properties}

The LF dry matter content occupied only a small proportion of the total soil mass (Table 3). At soil depth of $0-15 \mathrm{~cm}$, the LFOC concentrations under shrubs in 12- and 25-year-old $C$. microphylla plantations were 13.00 and 22.43 times higher than that in moving sand dunes, 
respectively. The LFOC storage values under shrubs in 12- and 25-year-old C. microphylla plantations were 17.84 and 28.80 times higher than that in moving sand dunes, respectively. Similarly, at soil depth of $0-15 \mathrm{~cm}$, the LFOC concentrations between shrubs in 12- and 25-year-old C. microphylla plantations were 6.43 and 12.71 times higher than that in moving sand dunes, respectively. The LFOC storage values between shrubs in 12- and 25-year-old $C$. microphylla plantations were 10.10 and 16.55 times higher than that in moving sand dunes, respectively. At soil depths of $0-5$ and $5-15 \mathrm{~cm}$, the percentage of LFOC concentration to SOC concentration was significantly lower in moving sand dunes than in 12- and 25-year-old $C$. microphylla plantations $(P<0.05)$.

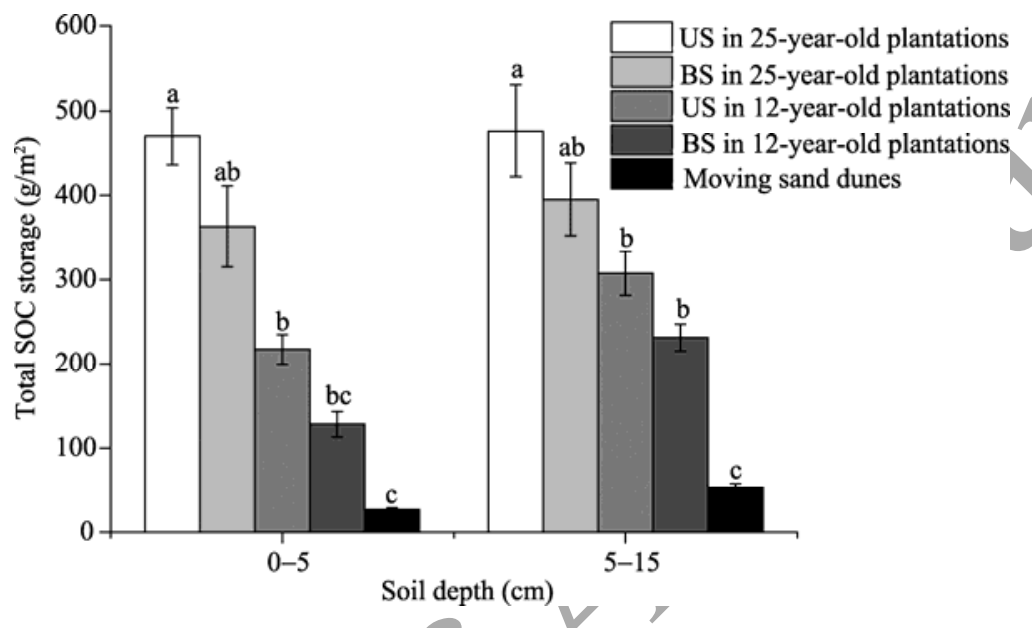

Fig. 1 Total SOC (soil organic carbon) storage at 0-5 and 5-15 cm soil depths in moving sand dunes (controls; 0 -year age of C. microphylla) and in 12- and 25-year-old C. microphylla plantations. Different lowercase letters represent significant difference at $P<0.05$ level in the corresponding depth and location. Bars mean standard errors. US, under shrubs; BS, between shrubs.

Table 3 Characteristics of light faction (LF) at different soil depths in moving sand dunes (controls; 0-year age of C. microphylla) and in 12- and 25-year-old C. microphylla plantations

\begin{tabular}{|c|c|c|c|c|c|c|}
\hline \multirow{3}{*}{ LF property } & \multirow{3}{*}{$\begin{array}{l}\text { Soil depth } \\
\text { (cm) }\end{array}$} & \multirow{3}{*}{$\begin{array}{l}\text { Moying } \\
\text { sand dunes }\end{array}$} & \multicolumn{4}{|c|}{ C. microphylla plantations } \\
\hline & & & \multicolumn{2}{|c|}{ 12-year-old } & \multicolumn{2}{|c|}{ 25-year-old } \\
\hline & & & $\begin{array}{l}\text { Under } \\
\text { shrubs }\end{array}$ & $\begin{array}{c}\text { Between } \\
\text { shrubs }\end{array}$ & $\begin{array}{l}\text { Under } \\
\text { shrubs }\end{array}$ & $\begin{array}{c}\text { Between } \\
\text { shrubs }\end{array}$ \\
\hline \multirow{6}{*}{$\begin{array}{l}\text { LF dry matter content } \\
(\%) \\
\text { LFOC concentration } \\
(\mathrm{g} / \mathrm{kg})\end{array}$} & & $0.10 \pm 0.03^{\mathrm{c}}$ & $0.38 \pm 0.04^{\mathrm{bc}}$ & $0.17 \pm 0.02^{\mathrm{c}}$ & $1.21 \pm 0.14^{\mathrm{a}}$ & $0.68 \pm 0.13^{b}$ \\
\hline & & $0.06 \pm 0.02^{\mathrm{a}}$ & $0.19 \pm 0.03^{\mathrm{a}}$ & $0.13 \pm 0.02^{\mathrm{a}}$ & $0.45 \pm 0.06^{\mathrm{a}}$ & $0.25 \pm 0.05^{\mathrm{a}}$ \\
\hline & & $0.08 \pm 0.02^{\mathrm{c}}$ & $0.28 \pm 0.04^{\mathrm{bc}}$ & $0.15 \pm 0.01^{\mathrm{bc}}$ & $0.83 \pm 0.14^{\mathrm{a}}$ & $0.46 \pm 0.09^{b}$ \\
\hline & $0-5$ & $0.08 \pm 0.03^{\mathrm{c}}$ & $1.22 \pm 0.11^{\mathrm{b}}$ & $0.52 \pm 0.06^{\mathrm{c}}$ & $2.26 \pm 0.21^{\mathrm{a}}$ & $1.30 \pm 0.17^{\mathrm{b}}$ \\
\hline & $5-15$ & $0.05 \pm 0.02^{\mathrm{b}}$ & $0.61 \pm 0.08^{\mathrm{ab}}$ & $0.37 \pm 0.06^{\mathrm{ab}}$ & $0.88 \pm 0.10^{\mathrm{a}}$ & $0.49 \pm 0.06^{\mathrm{ab}}$ \\
\hline & $0-15$ & $0.07 \pm 0.02^{\mathrm{c}}$ & $0.91 \pm 0.11^{\mathrm{b}}$ & $0.45 \pm 0.05^{\mathrm{bc}}$ & $1.57 \pm 0.24^{\mathrm{a}}$ & $0.89 \pm 0.15^{\mathrm{b}}$ \\
\hline \multirow{3}{*}{$\begin{array}{l}\text { LFOC storage } \\
\qquad\left(\mathrm{g} / \mathrm{m}^{2}\right)\end{array}$} & $0-5$ & $3.80 \pm 0.55^{\mathrm{c}}$ & $86.87 \pm 7.62^{\mathrm{b}}$ & $43.32 \pm 4.68^{\mathrm{ab}}$ & $157.83 \pm 28.22^{\mathrm{a}}$ & $104.63 \pm 22.67^{\mathrm{a}}$ \\
\hline & $5-15$ & $6.50 \pm 0.86^{\mathrm{b}}$ & $96.88 \pm 14.17^{\mathrm{a}}$ & $60.67 \pm 12.83^{\mathrm{ab}}$ & $138.77 \pm 31.39^{\mathrm{a}}$ & $65.79 \pm 18.83^{\mathrm{a}}$ \\
\hline & $0-15$ & $5.15 \pm 0.59^{b}$ & $91.87 \pm 7.54^{\mathrm{ab}}$ & $51.99 \pm 7.24^{\mathrm{ab}}$ & $148.30 \pm 20.33^{\mathrm{a}}$ & $85.21 \pm 15.22^{\mathrm{a}}$ \\
\hline \multirow{3}{*}{$\begin{array}{l}\text { Percentage of LFOC } \\
\text { concentration to SOC } \\
\text { concentration }(\%)\end{array}$} & $0-5$ & $5.84 \pm 2.79^{\mathrm{b}}$ & $40.70 \pm 3.11^{\mathrm{a}}$ & $31.60 \pm 2.77^{\mathrm{a}}$ & $33.47 \pm 1.86^{\mathrm{a}}$ & $27.32 \pm 1.81^{\mathrm{a}}$ \\
\hline & $5-15$ & $6.71 \pm 2.27^{\mathrm{b}}$ & $31.63 \pm 3.99^{\mathrm{a}}$ & $25.78 \pm 3.99^{\mathrm{a}}$ & $28.98 \pm 1.70^{\mathrm{a}}$ & $20.24 \pm 2.48^{\mathrm{a}}$ \\
\hline & $0-15$ & $6.34 \pm 1.70^{\mathrm{c}}$ & $36.16 \pm 2.77^{\mathrm{a}}$ & $28.69 \pm 2.48^{\mathrm{ab}}$ & $31.22 \pm 1.38^{\mathrm{a}}$ & $23.78 \pm 1.81^{\mathrm{b}}$ \\
\hline
\end{tabular}

Note: LFOC, light fraction organic carbon. Different lowercase letters within the same row represent significant differences among different sampling sites at $P<0.05$ level. Mean \pm SE; $n=9$.

\subsection{MBC properties}

MBC concentrations at soil depths of $0-5$ and 5-15 cm were higher in 12- and 25-year-old C. microphylla plantations than in moving sand dunes (Table 4). At soil depth of $0-15 \mathrm{~cm}$, the MBC 
storage values under shrubs in 12- and 25-year-old of C. microphylla plantations were 4.02 and 4.30 times more than that in moving sand dunes, respectively. The MBC storage values between shrubs in 12- and 25-year-old of C. microphylla plantations were 3.19 and 3.36 times more than that in moving sand dunes, respectively. Furthermore, no significant differences in the percentage of MBC concentration to SOC concentration were found among the sampling sites at soil depths of $0-5$ and 5-15 cm $(P>0.05)$, and the highest percentage of $\mathrm{MBC}$ concentration to SOC concentration was found in 12-year-old C. microphylla plantations. Generally speaking, afforestation in moving sand dunes resulted in the increases in $\mathrm{MBC}$ concentration, MBC storage and the percentage of $\mathrm{MBC}$ concentration to SOC concentration.

Table 4 Characteristics of microbial biomass carbon (MBC) at different soil depths in moving sand dunes (controls; 0-year age of C. microphylla) and in 12- and 25-year-old C. microphylla plantations

\begin{tabular}{|c|c|c|c|c|c|c|}
\hline \multirow{3}{*}{ MBC property } & \multirow{3}{*}{$\begin{array}{l}\text { Soil depth } \\
\quad(\mathrm{cm})\end{array}$} & \multirow{3}{*}{$\begin{array}{l}\text { Moving sand } \\
\text { dunes }\end{array}$} & \multicolumn{4}{|c|}{ C. microphylla plantations } \\
\hline & & & \multicolumn{2}{|c|}{ 12-year-old } & \multicolumn{2}{|c|}{ 25-year-old } \\
\hline & & & $\begin{array}{l}\text { Under } \\
\text { shrubs }\end{array}$ & $\begin{array}{c}\text { Between } \\
\text { shrubs }\end{array}$ & $\begin{array}{l}\text { Under } \\
\text { shrubs }\end{array}$ & $\begin{array}{c}\text { Between } \\
\text { shrubs }\end{array}$ \\
\hline \multirow{3}{*}{$\begin{array}{l}\text { MBC concentration } \\
(\mathrm{g} / \mathrm{kg})\end{array}$} & $0-5$ & $0.012 \pm 0.004^{\mathrm{b}}$ & $0.112 \pm 0.038^{\mathrm{a}}$ & $0.047 \pm 0.015^{\mathrm{ab}}$ & $0.111 \pm 0.018^{\mathrm{a}}$ & $0.089 \pm 0.028^{\mathrm{a}}$ \\
\hline & $5-15$ & $0.015 \pm 0.004^{\mathrm{a}}$ & $0.036 \pm 0.016^{\mathrm{a}}$ & $0.045 \pm 0.016^{\mathrm{a}}$ & $0.044 \pm 0.007^{\mathrm{a}}$ & $0.029 \pm 0.010^{\mathrm{a}}$ \\
\hline & $0-15$ & $0.014 \pm 0.003^{b}$ & $0.074 \pm 0.023^{\mathrm{a}}$ & $046 \pm$ & $0.077 \pm 0.014^{\mathrm{a}}$ & $0.059 \pm 0.017^{\mathrm{a}}$ \\
\hline \multirow{3}{*}{$\begin{array}{l}\text { MBC storage } \\
\left(\mathrm{g} / \mathrm{m}^{2}\right)\end{array}$} & $0-5$ & $1.01 \pm 0.32^{\mathrm{b}}$ & $8.02 \pm 3.38^{\mathrm{a}}$ & & $7.80 \pm 1.14^{\mathrm{a}}$ & $6.80 \pm 2.27^{\mathrm{a}}$ \\
\hline & $5-15$ & $2.41 \pm 0.59^{b}$ & $5.73 \pm 3.97^{\mathrm{ab}}$ & & $6.90 \pm 0.60^{\mathrm{a}}$ & $4.68 \pm 2.04^{\mathrm{ab}}$ \\
\hline & $0-15$ & $1.71 \pm 0.36^{\mathrm{b}}$ & $6.88 \pm 2.39^{\mathrm{a}}$ & $5.45 \pm 1.42^{\mathrm{a}}$ & $7.35 \pm 0.61^{\mathrm{a}}$ & $5.74 \pm 1.45^{\mathrm{a}}$ \\
\hline \multirow{3}{*}{$\begin{array}{l}\text { Percentage of MBC } \\
\text { concentration to SOC } \\
\text { concentration }(\%)\end{array}$} & $0-5$ & $1.48 \pm 0.64^{\mathrm{a}}$ & $3.47 \pm 0$ & $3.07 \pm 1.20^{\mathrm{a}}$ & $1.69 \pm 0.29^{\mathrm{a}}$ & $1.79 \pm 0.40^{\mathrm{a}}$ \\
\hline & $5-15$ & $1.86 \pm 0.96^{\mathrm{a}}$ & $1.79 \pm 0.75^{\mathrm{a}}$ & $3.13 \pm 1.12^{\mathrm{a}}$ & $1.43 \pm 0.16^{\mathrm{a}}$ & $1.23 \pm 0.41^{\mathrm{a}}$ \\
\hline & $0-15$ & $1.63 \pm 0.51^{\mathrm{a}}$ & $2.63 \pm 0.62$ & $3.10 \pm 0.78^{\mathrm{a}}$ & $1.56 \pm 0.61^{\mathrm{a}}$ & $1.51 \pm 0.29^{\mathrm{a}}$ \\
\hline
\end{tabular}

Note: Different lowercase letters within the same row represent significant differences among different sampling sites at $P<0.05$ level. Mean \pm SE; $n=9$.

\subsection{Accumulation rates of total SOC, LFOC and MBC storages}

The average accumulation rates of total SOC, LFOC and MBC storages at soil depth of 0-15 cm under shrubs and between shrubs in C. microphylla plantations are shown in Figure 2. At soil depth of $0-15 \mathrm{~cm}$, the average accumulation rates of total SOC storage under shrubs in C. microphylla plantations were $18.53,16.24$ and $17.34 \mathrm{~g} \mathrm{C} /\left(\mathrm{m}^{2} \cdot \mathrm{a}\right)$ for the age groups of $0-12,12-25$ and $0-25$ years, respectively; while the values were $11.66,15.34$ and $13.57 \mathrm{~g} \mathrm{C} /\left(\mathrm{m}^{2} \cdot \mathrm{a}\right)$ between shrubs in $C$. microphylla plantations for the age groups of $0-12,12-25$ and $0-25$ years, respectively. Further, the average accumulation rate of total SOC storage was greater under shrubs than between shrubs in C. microphylla plantations for the age group of 0-12 years. However, similar accumulation rates weré observed under shrubs and between shrubs in C. microphylla plantations for the age group of 12-25 years. Compared with the average accumulation rate of total SOC storage, the average accumulation rate of LFOC storage was lower, with respective values of 7.23, 4.34 and $5.73 \mathrm{~g}$ $\mathrm{C} /\left(\mathrm{m}^{2} \cdot \mathrm{a}\right)$ under shrubs and $3.90,2.56$ and $3.20 \mathrm{~g} \mathrm{C} /\left(\mathrm{m}^{2} \cdot \mathrm{a}\right)$ between shrubs in C. microphylla plantations for the age groups of $0-12,12-25$ and $0-25$ years.

\subsection{Relationships between SOC fractions}

Relationships between SOC fractions (including total SOC concentration, LF dry matter content, LFOC concentration, MBC concentration, and percentages of LFOC concentration to SOC concentration and MBC concentration to SOC concentration) are shown in Table 5. LFOC concentration was significantly correlated with total SOC and $\mathrm{MBC}$ concentrations, as well as with LF dry mater content and the percentage of LFOC concentration to SOC concentration $(P<0.01)$. Moreover, MBC concentration also showed significant positive correlations with total SOC concentration and LFOC concentration, as well as with the percentages of LFOC concentration to SOC concentration and MBC concentration to SOC concentration $(P<0.01)$. 

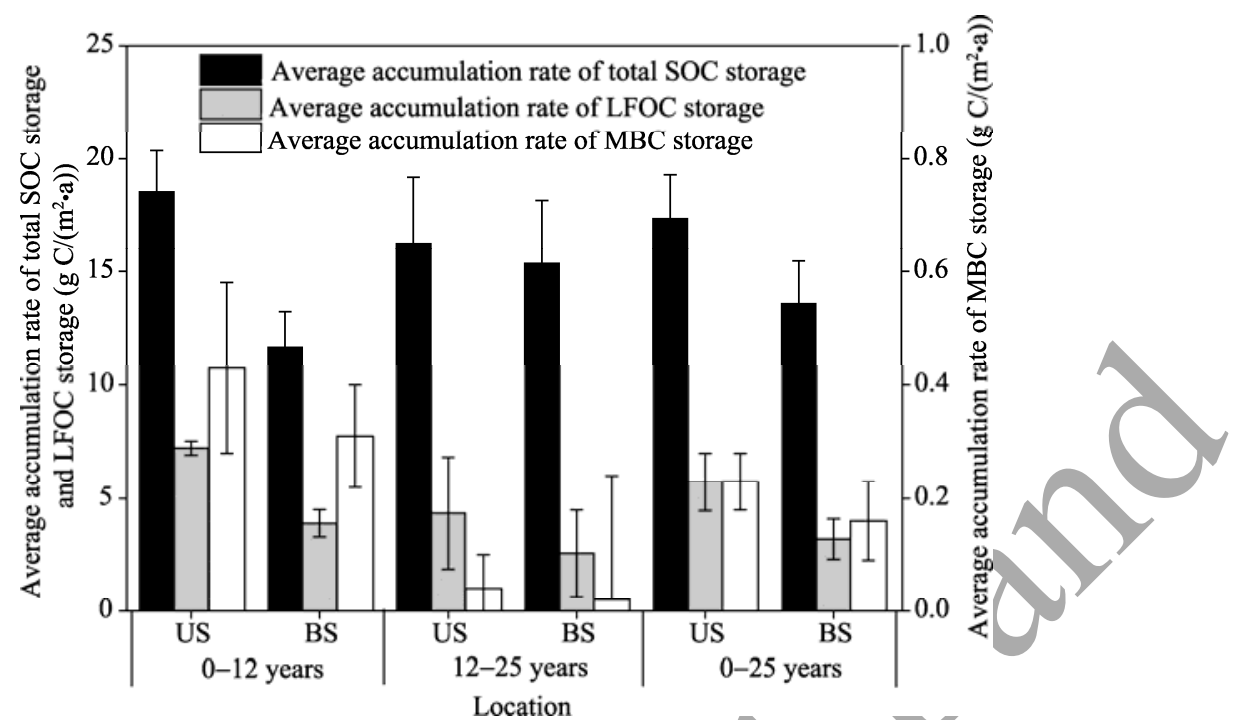

Fig. 2 Average accumulation rates of total SOC storage, LFOC (light fraction organic carbon) storage, and MBC (microbial biomass carbon) storage at soil depth of $0-15 \mathrm{~cm}$ under shrubs (US) and between shrubs (BS) in C. microphylla plantations for age groups of $0-12,12-25$ and $0-25$ years. Bars mean standard errors.

Table 5 Pearson's correlation coefficients between SOC fractions in moving sand dunes (controls; 0-year age of C. microphylla) and in 12- and 25-year-old C. microphylla plantations

\begin{tabular}{|c|c|c|c|c|c|c|}
\hline & SOC concentration & LF dry matter content & $\begin{array}{c}\text { LFOC } \\
\text { concentration }\end{array}$ & $\begin{array}{c}\mathrm{MBC} \\
\text { concentration }\end{array}$ & $\begin{array}{c}\text { LFOC } \\
\text { percentage }\end{array}$ & $\begin{array}{c}\text { MBC } \\
\text { percentage }\end{array}$ \\
\hline SOC concentration & 1.000 & & & & & \\
\hline LF dry matter content & $0.928^{* *}$ & & & & & \\
\hline LFOC concentration & $0.946^{* *}$ & & 1.000 & & & \\
\hline MBC concentration & $0.613^{* *}$ & $0.516^{* *}$ & $0.588^{* *}$ & 1.000 & & \\
\hline LFOC percentage & $0.525^{* *}$ & $0.426^{* *}$ & $0.610^{* *}$ & $0.411^{* *}$ & 1.000 & \\
\hline MBC percentage & -0.043 & -0.070 & 0.012 & $0.630^{* *}$ & 0.089 & 1.000 \\
\hline
\end{tabular}

Note: LFOC percentage represent the percentage of LFOC concentration to SOC concentration; MBC percentage represent the percentage of MBC concentration to SOC concentration. ${ }^{* *}$ indicates significance at $P<0.01$ level. $n=9$.

\section{Discussion}

\subsection{Effects of C. microphylla plantations on total SOC}

In this study, afforestation with C. microphylla shrubs on moving sand dunes resulted in increases in total SOC concentration and storage at soil depths of $0-5$ and $5-15 \mathrm{~cm}$ (Table 2; Fig. 1). Furthermore, both total SOC concentration and storage increased with plantation age of $C$. microphylla. Our finding is in accordance with the result of $\mathrm{Su}$ and Zhao (2003). For 12- and 25-year-old C. microphylla plantations, the increasing inputs of organic $\mathrm{C}, \mathrm{N}$ and other nutrients from plant litter and root residues after afforestation are retained as particulate organic matter or fixed into mineral particles, contributing to SOC sequestration (Del Galdo et al., 2003; Giardina et al., 2004). In addition, the growth of C. microphylla shrubs can decrease soil temperature and slow SOC loss via limited microbial decomposition in lower temperature conditions (Laganière et al., 2010), and the increased silt+clay content after afforestation with C. microphylla shrubs can both reduce the decomposition rate of organic matter via SOC stabilization and decrease the C leaching, thus resulting in SOC sequestration (Schimel et al., 1994; Torn et al., 1997; Jobbágy and Jackson, 2000). At soil depths of $0-5$ and $5-15 \mathrm{~cm}$, SOC storage was higher in 12- and 25 -year-old C. microphylla plantations than in moving sand dunes. In addition, SOC storage was also greater under shrubs than between shrubs for both 12- and 25-year-old C. microphylla plantations (Fig. 1). This indicates that C. microphylla plantations have strong potential to act as 
$\mathrm{C}$ sinks for C-poor soils in the semi-arid sandy regions of northern China, and this effect is more significant under C. microphylla shrubs than between C. microphylla shrubs ( $\mathrm{Su}$ and Zhao, 2003; Cao et al., 2008).

\subsection{Effects of $C$. microphylla plantations on labile SOC fractions}

In this study, the concentrations and storages of LFOC and MBC at soil depth of $0-15 \mathrm{~cm}$ were much higher in 12- and 25-year-old C. microphylla plantations than in moving sand dunes (Tables 3 and 4), implying that afforestation with C. microphylla shrubs could improve the $\mathrm{C}$ quality of surface soils in degraded sandy land. The increased concentrations and storages of LFOC and MBC may have been resulted from the stabilization of plant residues and fine root detritus after afforestation (Wang et al., 2013; Lai et al., 2017). This improvement could enhance soil microbial abundance and enzyme activity (Li et al., 2012; Wang et al., 2013), resulting in the increased labile SOC fractions in afforested C. microphylla plantations. Significant positive correlations among LFOC, MBC and SOC concentrations (Table 5) suggest that the gradually increased SOC input from plant detritus and rhizosphere products in 12- and 25-year-old C. microphylla plantations provides more available nutrients for soil microbes and thus increases the concentrations and storages of soil LFOC and MBC. Furthermore, the greater values of LFOC and MBC under shrubs in 25-year-old C. microphylla plantations than in 12-year-old C. microphylla plantations indicate that soil $\mathrm{C}$ quality can be improved gradually with plantation age, and the accumulations are mainly concentrated under shrubs rather than between shrubs. At soil depth of $0-15 \mathrm{~cm}$, the LFOC storage ranged from $5.15 \mathrm{~g} / \mathrm{m}^{2}$ in moving sand dunes to $148.30 \mathrm{~g} / \mathrm{m}^{2}$ in 25 -year-old C. microphylla plantations (Table 3), whereas the total SOC storage ranged from $39.79 \mathrm{~g} / \mathrm{m}^{2}$ in moving sand dunes to $473.28 \mathrm{~g} / \mathrm{m}^{2}$ in 25 -year-old C. microphylla plantations (Fig. 1). These differences support the previous finding that LFOC is more sensitive to vegetation restoration than total SOC in the Horqin Sandy Land (Li et al., 2012).

Generally speaking, the proportion of LFOC in the SOC varies greatly among different climatic regimes and plant species. For examples, Xie et al. (2013) found that the percentage of LFOC concentration to SOC concentration ranged from $4.24 \%$ before afforestation to $38.28 \%$ after afforestation of Pinus massoniana plantations (24-year-old) at soil depth of $0-60 \mathrm{~cm}$ in a subtropical region. Laik et al.(2009) noted that afforestation with different tree species increased the LFOC and the percentage of LFOC concentration to SOC concentration in different plantations (ranging from $9.61 \%$ before afforestation to $11.71 \%$ after afforestation) at soil depth of $0-30 \mathrm{~cm}$. Our results showed that the percentage of LFOC concentration to SOC concentration at soil depth of $0-15 \mathrm{~cm}$ ranged from $5.84 \%$ in moving sand dunes (before afforestation) to $40.70 \%$ in C. microphylla plantations (after afforestation) (Table 3). The relatively high percentage of LFOC concentration to SOC concentration in this study was primarily resulted from the semi-arid climate and drier soil conditions in the study area. Drier conditions constrained the decomposition rate of plant litter and thus led to a greater accumulation of light fraction (Janzen et al., 1992; Gregorich et al., 2006). Furthermore, the higher percentage of LFOC concentration to SOC concentration in 12-year-old C. microphylla plantations compared with that in 25-year-old C. microphylla plantations indicates that the partially decomposed plant residues accumulates in the young plantations more effectively.

The percentage of MBC concentration to SOC concentration in 12- and 25-year-old C. microphylla plantations ranged from $1.23 \%$ to $3.47 \%$ (Table 4 ), falling in the range of $1 \%-3 \%$ concluded by Jenkinson (1988). The percentage of MBC concentration to SOC concentration was higher in 12- and 25-year-old C. microphylla plantations than in moving sand dunes, suggesting that the easily decomposed organic $\mathrm{C}$ accounts for a high proportion of total soil organic $\mathrm{C}$ compared to the stable humus fraction (Anderson and Domsch, 1989). The higher percentage of MBC concentration to SOC concentration in 12-year-old C. microphylla plantations compared with that in 25-year-old C. microphylla plantations also implies that the available organic $\mathrm{C}$ is higher at relatively young plantations. After planting trees in moving dunes, tree roots and root secretion alter the soil environment by increasing soil organic matter, and consequently soil organic matter ensures microorganism growth and regeneration (Yang et al., 2005). 


\subsection{Organic $\mathrm{C}$ accumulation in total and labile fractions}

At soil depth of $0-15 \mathrm{~cm}$, the average accumulation rates of total SOC storage ranged from 11.66 to $18.53 \mathrm{~g} \mathrm{C} /\left(\mathrm{m}^{2} \cdot \mathrm{a}\right)$ (Fig. 2). This indicates that afforestation with shrubs contributes to SOC sequestration in the Horqin Sandy Land. It should be noted that the average SOC accumulation rates in our study were lower than those in other previous studies. For example, Xie et al. (2013) reported that the average SOC accumulation rate at soil depth of $0-100 \mathrm{~cm}$ following afforestation was $105 \mathrm{~g} \mathrm{C} /\left(\mathrm{m}^{2} \cdot \mathrm{a}\right)$ in the subtropical regions. Shi et al. (2015) reported that the average SOC accumulation rate at soil depth of $0-60 \mathrm{~cm}$ in shrub-dominated afforestation sites of the high-altitude Qinghai Plateau was $113.3 \mathrm{~g} \mathrm{C} /\left(\mathrm{m}^{2} \cdot \mathrm{a}\right)$. One explanation for the difference is that both annual precipitation and annual temperature in the Horqin Sandy Land $\left(362 \mathrm{~mm}\right.$ and $6.4^{\circ} \mathrm{C}$, respectively) are lower than those in the subtropical regions $\left(1737 \mathrm{~mm}\right.$ and $18.1^{\circ} \mathrm{C}$, respectively), thus the sandy soils in the Horqin Sandy Land are drier and cooler, ultimately slowing down the decomposition rates of SOC. It is worthy to mention that the SOC accumulation rate could even differ for the similar climate conditions and/or prior land-use types. For example, Vesterda et al. (2007) noted that the mineral $\mathrm{C}$ accumulation rate after afforestation with oak or spruce on temperate sandy soils ranged from 9 to $114 \mathrm{~g} \mathrm{C} /\left(\mathrm{m}^{2} \cdot \mathrm{a}\right)$ in Denmark. Li et al. (2012) reported that the SOC accumulation rate at soil depth of $0-15 \mathrm{~cm}$ after afforestation with Mongolian pine varied from 15.5 to $30.8 \mathrm{~g} \mathrm{C} /\left(\mathrm{m}^{2} \cdot \mathrm{a}\right)$ in the semi-arid Horqin Sandy Land. It was recently reported that prior land use of afforested sites might have limited effects on SOC accumulation, whereas climate conditions, plant species, plantation ages and soil sampling depths could be the major factors determining SOC sequestration in shrub plantations (Shi et al., 2015).

Effects of afforestation chronosequences on sandy lands have been previously investigated in the Horqin Sandy Land (Su and Zhao, 2003; Hu et al., 2008; Li et al., 2012). For example, Li et al. (2012) stated that the average SOC accumulation rate at soil depth of $0-15 \mathrm{~cm}$ was lower in young Mongolian pine plantations (0-25 years) than in old Mongolian pine plantations (25-35 years). However, opposite pattern was observed in this study. That is, the average SOC accumulation rate was higher in young C. microphylla plantations $(0-12$ years) than in old $C$. microphylla plantations (12-25 years) (Fig. 2). This may be due to the great leaf amounts of new plants and the new plants increased litter production and tightened nutrient recycling in young shrub plantations (Bradshaw, 1983). Similar pattern was also observed by Bhojvaid and Timmer (1998) who examined the restoration effects of Prosopis juliflora plantations on degraded sites. Further, the average SOC accumulation rates were higher under shrubs than between shrubs in $C$. microphylla plantations for ages of 0-12 years, whereas similar accumulation rates were found under shrubs and between shrubs in C. microphylla plantations for ages of 12-25 years (Fig. 2). $\mathrm{Su}$ and Zhao (2003) noted that the growth of herbaceous species and the development of $C$. microphylla roots between shrubs would result in a decrease in spatial heterogeneity of SOC with increasing plantation age.

Similarly, at soil depth of $0-15 \mathrm{~cm}$, the average accumulation rates of LFOC and MBC under shrubs and between shrubs were higher in young C. microphylla plantations (0-12 years) than in old C. microphylla plantations (12-25 years) (Fig. 2), indicating that the sequestration rates of labile SOC fractions are greater in the early plantation stage. The finding in our study is in accordance with the observation of Nadal-Romero et al. (2016) who reported that the first step of SOC stabilization after afforestation is the formation of macro-aggregates promoted by large inputs of SOC with a high contribution of labile organic matter. After investigating the changes of soil enzyme activity in the chronosequence of $C$. microphylla plantations in the Horqin Sandy Land, Teng et al. (2007) divided the changes of soil enzyme activity into three stages: (1) slow growth stage ( $0-5$ years); (2) fast growth stage (5-10 years); and (3) slow improvement stage (10-22 years). In the fast growth stage, when the moving sand dunes were completely fixed, the increasing amounts of fresh plant leaves and branches could provide more easily decomposed nutrients, and soil organic matter and enzyme diversity tended to increase. The drier soil conditions during the young plantation stage restricted the decomposition rate of soil organic matter, ultimately resulting in higher accumulation rates of soil organic matter. However, in old $C$. 
microphylla plantations (12-25 years), plant diversity was largely increased but the growth rates of soil microbial biomass and enzyme activity were slower, thus the accumulation rates of labile SOC fractions became lower. Additionally, the accumulation rates of LFOC and MBC under shrubs and between shrubs were both lower than those of total SOC (Fig. 2). We speculate that not only labile SOC fractions but also other fractions such as slower and recalcitrant SOC fractions may have contributed to SOC sequestration after the establishment of C. microphylla on moving sand dunes in the Horqin Sandy Land.

\section{Conclusions}

This study demonstrates that the total and labile SOC fractions show significant increases in the first 12 years after afforestation with C. microphylla shrubs on moving sand dunes in the Horqin Sandy Land. The storages of total SOC, LFOC, and MBC were higher under shrubs than between shrubs. Our results indicate that afforestation with C. microphylla shrubs on moving sand dunes has the potential to sequester organic $\mathrm{C}$ into surface soils. And, this effect is greater under shrubs than between shrubs and the effect becomes greater with increasing plantation age. Furthermore, this study demonstrates that after afforestation with $C$. microphylla shrubs on moving sand dunes, the sequestrations of total and labile SOC fractions are high under shrubs in young C. microphylla plantations.

\section{Acknowledgements}

This study was funded by the National Natural Science Foundation of China (31640012, 41271007, 31660232), the One Hundred Person Project of the Chinese Academy of Sciences (Y551821), and the Opening Foundation of the State Key Laboratory Breeding Base of Desertification and Aeolian Sand Disaster Combating, Gansu Desert Control Research Institute (GSDC201505). The authors are grateful to the staff of the Naiman Desertification Research Station of Chinese Academy of Sciences for their assistance with this study.

\section{References}

Anderson T H, Domsch K H. 1989. Ratios of microbial biomass carbon to total organic carbon in arable soils. Soil Biology \& Biochemistry, 21(4): 471-479.

Arai H, Tokuchi N. 2010. Factors contributing to greater soil organic carbon accumulation after afforestation in a Japanese coniferous plantation as determined by stable and radioactive isotopes. Geoderma, 157(3-4): 243-251.

Bárcena T G, Gundersen P, Vesterdal L. 2014. Afforestation effects on SOC in former cropland: oak and spruce chronosequences resampled after 13 years. Global Change Biology, 20(9): 2938-2952.

Berthrong S T, Piñeiro G, Jobbágy E G, et al. 2012. Soil C and N changes with afforestation of grasslands across gradients of precipitation and plantation age. Ecological Application, 22(1): 76-86.

Bhojvaid P P, Timmer V R. 1998. Soil dynamics in an age sequence of Prosopis juliflora planted for sodic soil restoration in India. Forest Ecology and Management, 106(2-3): 181-193.

Bradshaw A D. 1983. The reconstruction of ecosystems: Presidential address to the British ecological society, December 1982. Journal of Applied Ecology, 20(1): 1-17.

Cao C Y, Jiang D M, Teng X H, et al. 2008. Soil chemical and microbiological properties along a chronosequence of Caragana microphylla Lam. plantations in the Horqin Sandy Land of Northeast China. Applied Soil Ecology, 40(1): $78-85$.

Del Galdo I, Six J, Peressotti A, et al. 2003. Assessing the impact of land-use change on soil C sequestration in agricultural soils by means of organic matter fractionation and stable C isotopes. Global Change Biology, 9(8): 1204-1213.

Deng L, Wang K B, Shangguan Z P. 2014. Long-term natural succession improves nitrogen storage capacity of soil on the Loess Plateau, China. Soil Research, 52(3): 262-270.

Deng L, Shangguan Z P. 2016. Afforestation drives soil carbon and nitrogen changes in China. Land Degradation \& Development, 28(1): 151-165.

Duan Z H, Xiao H L, Dong Z B, et al. 2007. Morphological, physical and chemical properties of aeolian sandy soils in northern China. Journal of Arid Environments, 68(1): 66-76.

Giardina C P, Binkley D, Ryan M G, et al. 2004. Belowground carbon cycling in a humid tropical forest decreases with 
fertilization. Oecologia, 139(4): 545-550.

Gregorich E G, Beare M H, McKim U F, et al. 2006. Chemical and biological characteristics of physically uncomplexed organic matter. Soil Science Society of America Journal, 70(3): 975-985.

Han X H, Zhao F Z, Tong X G, et al. 2017. Understanding soil carbon sequestration following the afforestation of former arable land by physical fractionation. Catena, 150: 317-327.

Higginbottom T P, Symeonakis E. 2014. Assessing land degradation and desertification using vegetation index data: current frameworks and future directions. Remote Sensing, 6(10): 9552-9575.

Hu Y L, Zeng D H, Fan Z P, et al. 2008. Changes in ecosystem carbon stocks following grassland afforestation of semiarid sandy soil in the southeastern Keerqin Sandy Lands, China. Journal of Arid Environment, 72(12): 2193-2200.

Huang W D, Zhao X Y, Zhao X, et al. 2016. Effects of environmental factors on genetic diversity of Caragana microphylla in Horqin Sandy Land, northeast China. Ecology and Evolution, 6(22): 8256-8266.

ISO (International Organization for Standardization). 1998. ISO 11277: soil quality-determination of particle size distribution in mineral soil material-method by sieving and sedimentation. Geneva, Switzerland: ISO.

Janzen H H, Campbell C A, Brandt S A, et al. 1992. Light fraction organic matter in soils from long-term crop rotations. Soil Science Society of America Journal, 56(6): 1799-1806.

Jenkinson D S. 1988. The determination of microbial biomass carbon and nitrogen in soil. In Wilson J R. Advances in Nitrogen Cycling in Agricultural Ecosystems. Wallingford, UK: CAB International, 368-386.

Jobbágy E G, Jackson R B. 2000. The vertical distribution of soil organic carbon and its relation to climate and vegetation. Ecological Application, 10(2): 423-436.

Lai Z R, Liu J B, Zhang Y Q, et al. 2017. Introducing a shrub species in a degraded steppe shifts fine root dynamics and soil organic carbon accumulations, in northwest China. Ecological Engineering, 100: 277-285.

Laganière J, Angers D A, Pare D. 2010. Carbon accumulation in agricultural soils after afforestation: a meta-analysis. Global Change Biology, 16(1): 439-453.

Laik R, Kumar K, Das D K, et al. 2009. Labile soil organic matter pools in a calciorthent after 18 years of afforestation by different plantations. Applied Soil Ecology, 42(2): 71-78.

Lal R. 2001. Potential of desertification control to sequester carbon and mitigate the greenhouse effect. Climatic Change, 51(1): 35-72.

Lal R. 2014. Desertification and soil erosion. In: Freedman B. Global Environmental Change. Netherlands: Springer, 369-378.

Li Y L, Chen J, Cui J Y, et al. 2012. Nutrient resorption in Caragana microphylla along a chronosequence of plantations: implications for desertified land restoration in North China. Ecological Engineering, 53: 299-305.

Li Y Q, Awada T, Zhou X H, et al. 2012. Mongolian pine plantations enhance soil physico-chemical properties and carbon and nitrogen capacities in semi-arid degraded sandy land in China. Applied Soil Ecology, 56: 1-9.

Liu S J, Zhang W, Wang K L, et al. 2015. Factors controlling accumulation of soil organic carbon along vegetation succession in a typical Karst region in southwest China. Science of the Total Environment, 521-522: 52-58.

Nadal-Romero E, Cammeraat E, Serrano-Muela M P, et al. 2016. Hydrological response of an afforested catchment in a Mediterranean humid mountain area: A comparative study with a natural forest. Hydrological Processes, 30(15): $2717-2733$

Paul K I, Polglase P J, Nyakuengama J G, et al. 2002. Change in soil carbon following afforestation. Forest Ecology and Management, 168(1-3): 241-257.

Post W M, Kwon K C. 2000. Soil carbon sequestration and land-use change: processes and potential. Global Change Biology, 6(3): 317-327.

Rytter R-M. 2016. Afforestation of former agricultural land with Salicaceae species-initial effects on soil organic carbon, mineral nutrients, C:N and pH. Forest Ecology and Management, 363: 21-30.

Schimel D S, Braswell B H, Holland E A, et al. 1994. Climatic, edaphic, and biotic controls over storage and turnover of carbon in soils. Global Biogeochemical Cycles, 8(3): 279-293.

Shi S W, Han P F, Zhang P, et al. 2015. The impact of afforestation on soil organic carbon sequestration on the Qinghai Plateau, China. PLoS ONE, 10(2): e0116591.

Su Y Z, Zhao H L. 2003. Soil properties and plant species in an age sequence of Caragana microphylla plantations in the Horqin Sandy Land, north China. Ecological Engineering, 20(3): 223-235.

Tang G Y, Li K. 2013. Tree species controls on soil carbon sequestration and carbon stability following 20 years of afforestation in a valley-type savanna. Forest Ecology and Management, 291: 13-19.

Teng X H, Cao C Y, Fu Y, et al. 2007. Changes of soil enzyme activities and microbial biomass in an age sequence of 
Caragana microphylla plantation for sand-fixation. Ecological Environment, 16(3): 1030-1034. (in Chinese)

Torn M S, Trumbore S E, Chadwick O A, et al. 1997. Mineral control of soil organic carbon storage and turnover. Nature, 389(6647): 170-173.

UNCCD. 1994. United Nations Convention to combat Desertification in those countries experiencing serious drought and/or desertification, particularly in Africa. Geneva: UNEP.

Vance E D, Brookes P C, Jenkinson D S. 1987. An extraction method for measuring soil microbial biomass C. Soil Biology and Biochemistry, 19(6): 703-707.

Vesterda L, Rosenqvist L, Van Der Salm C, et al. 2007. Carbon sequestration in soil and biomass following afforestation: experiences from oak and Norway spruce chronosequences in Denmark, Sweden and the Netherlands. In: Heil G W, Muys B, Hansen K. Environmental Effects of Afforestation in North-Western Europe. Netherlands: Springer, 1: 19-51.

Wang H M, Wang W J, Chen H F, et al. 2014. Temporal changes of soil physic-chemical properties at different soil depths during larch afforestation by multivariate analysis of covariance. Ecology and Evolution, 4(7): 1039-1048.

Wang K B, Deng L, Ren Z P, et al. 2016. Dynamics of ecosystem carbon stocks during vegetation restoration on the Loess Plateau of China. Journal of Arid Land, 8(2): 207-220.

Wang S K, Zhao X Y, Zhang T H, et al. 2013. Afforestation effects on soil microbial abundance, microbial biomass carbon and enzyme activity in dunes of Horqin Sandy Land, northeastern China. Sciences in Cold and Arid Regions, 5(2): 184-190.

Wissing L, Kolbl A, Vogelsang V, et al. 2011. Organic carbon accumulation in a 2000-year chronosequence of paddy soil evolution. Catena, 87(3): 376-385.

Xie J S, Guo J F, Yang Z J, et al. 2013. Rapid accumulation of carbon on severely eroded red soils through afforestation in subtropical China. Forest Ecology and Management, 300: 53-59.

Yang T, Xu H, Li H, et al. 2005. Soil nutrient, microorganism and enzyme activity in Pinuse sylvestris plantations. Journal of Soil and Water Conservation, 19(3): 50-53. (in Chinese)

Yue G Y, Zhao H L, Zhang T H, et al. 2008. Evaluation of water use of Caragana microphylla with the stem heat-balance method in Horqin Sandy Land, Inner Mongolia, China. Agricultural and Forest Meteorology, 148(11): 1668-1678.

Zhang T H, Su Y Z, Cui J Y, et al. 2006. A leguminous shrub (Caragana microphylla) in semiarid sandy soils of North China. Pedosphere, 16(3): 319-325.

Zhao H L, Zhou R L, Su Y Z, et al. 2007. Shrub facilitation of desert land restoration in the Horqin Sand Land of Inner Mongolia. Ecological Engineering, 31(1): 1-8. 